\title{
MAKNA BAIT ALLAH DALAM 1 KORINTUS 3:16-17 DAN IMPLIKASINYA \\ BAGI ORANG PERCAYA MASA KINI
}

\author{
Herman Lesmana ${ }^{1}$ \\ Robi Panggarra ${ }^{2}$ \\ sttjaffraymakassar@yahoo.co.id
}

\begin{abstract}
ABSTRAK
Sesuai dengan pokok masalah yang ada, maka yang menjadi tujuan dalam penulisan karya ilmiah adalah: Pertama, untuk mengetahui pengertian yang benar tentang konsep orang percaya adalah bait Allah seperti yang dijelaskan dalam 1 Korintus 3:16-17. Kedua, untuk memberikan gambaran implikasi makna Bait Allah dalam kehidupan orang percaya masa kini.

Kesimpulan karya ilmiah ini adalah: Pertama, Bait Allah berarti kumpulan orang percaya. Sebagai kumpulan orang percaya, maka Bait Allah terdiri dari orangorang yang percaya kepada Kristus. Kedua, Bait Allah adalah tempat kediaman Allah. Dalam surat Korintus ini, kehadiran Allah ditengah-tengah umat-Nya diungkapkan dalam kehadiran Roh-Nya. Ketiga, Bait Allah itu harus dipelihara. Bait Allah sebagai bangunan milik Allah tidak boleh dibinasakan atau dihancurkan dengan cara apapun. Bait Allah harus dijaga kemurniannya dan keberadaannya sebagai tempat yang menyatakan kebenaran Allah. Keempat, Bait Allah itu kudus. Bait Allah sebagai orang percaya dikatakan kudus karena mereka adalah milik Allah dan Allah berdiam di dalam mereka.

Implikasi makna Bait Allah tersebut bagi orang percaya masa kini adalah: Pertama, Orang percaya masa kini patut hidup dalam kesatuan. Kedua, hidup dalam penyembahan. Ketiga, hidup dalam kekudusan. Sebagai Bait Allah rohani, orang percaya masa kini patut hidup dalam kekudusan yang sejati. Keempat, hidup dalam pelayanan. Pelayanan adalah anugerah yang diberikan Tuhan kepada setiap orang percaya sesuai dengan karunia yang dimilikinya.
\end{abstract}

Kata kunci: Makna Bait Allah, 1 Korintus 3:16-17

\footnotetext{
${ }^{1}$ Alumni Sl Sekolah Tinggi Theologia Jaffray 2013

${ }^{2}$ Dosen STT Jaffray
} 


\section{PENDAHULUAN}

\section{Latar Belakang Masalah}

Bait Allah dapat juga dikatakan sebagai bangunan dimana bangsa Israel memusatkan kehidupannya sepanjang waktu. Bait Allah adalah tempat dimana mereka mempersembahkan korban mereka bagi Allah (Im. 1-7). Bait Allah juga menjadi tempat pertemuan bagi mereka (Kis. 2:46), sebagai tempat pengajaran (Kis. 5:20-21). Bait Allah juga merupakan tempat pertukaran informasi dan pengetahuan (Luk. 21:37).

Keberadaan Bait Allah bagi bangsa Israel sesungguhnya tidak dimulai ketika Daud mempersiapkan bahan-bahan bangunan (1 Taw. 29:1-19), atau setelah Salomo membangunnya (1 Raj. 6-8; 2 Taw. 3-5), tetapi dimulai ketika Allah memerintahkan Musa untuk membangun sebuah Kemah Suci. Allah memerintahkan kepada Musa di Gunung Sinai untuk membuat tempat kudus bagi Tuhan, supaya Tuhan akan diam di tengah mereka (Kel.25:8). Keinginan Allah untuk menemui umat-Nya dalam suatu tempat pertemuan menyatakan terjadinya persekutuan antara Allah dengan umat-Nya. Hal ini menurut Jusuf B. S. menjadi "rahasia hidup umat Israel untuk bertahan mengarungi padang pasir menuju tanah Kanaan."

Paulus adalah seorang yang memiliki pendidikan cukup tinggi dalam hal keagamaan. Ia menyatakan hal tersebut dalam Galatia 1:13-14 "Sebab kamu telah mendengar tentang hidupku dahulu dalam agama Yahudi: tanpa batas aku menganiaya jemaat Allah dan berusaha membinasakannya. Dan di dalam agama Yahudi aku jauh lebih maju dari banyak teman yang sebaya dengan aku di antara bangsaku, sebagai orang yang sangat rajin memelihara adat istiadat nenek moyangku." Paulus adalah seorang anak Hukum Taurat. Ia juga menjadi seorang rabi seperti guru besar jaman sekarang. Oleh sebab itu Paulus sangat mengenal tentang Bait Allah. ${ }^{4}$

Pengenalan pertemuan Paulus dengan jemaat Korintus terjadi saat perjalanan penginjilan Paulus yang kedua. Ia tinggal di kota ini selama 18 bulan dan selama pelayanannya banyak orang Korintus menjadi Kristen. Dari pelayanan Paulus ini kemudian terbentuk suatu jemaat Kristen

19.

${ }^{3}$ Jusuf B. S., Kemah Suci-Pelajaran Alkitab dalam Keluaran 25 - 40, Jilid I (np: 1994),

${ }^{4}$ William Barclay, Duta Bagi Kristus-Latar Belakang Peta Perjalanan Paulus (Jakarta: BPK Gunung Mulia, 1985), 9-13. 
yang besar dan sangat berpengaruh di kota ini. ${ }^{5}$ Mereka juga kaya dalam pengetahuan dan karunia dalam Kristus (1 Kor. 1:4-9). Kompleksitas jemaat di Korintus tidak jauh berbeda dengan jemaat masa kini. Jemaat masa kini berada dalam konteks dan lingkungan yang hampir sama dengan situasi kota Korintus saat itu. Jemaat masa kini menghadapi persoalan doktrinal - praktikal; bentuk persoalan yang juga dialami jemaat di Korintus. Dengan demikian, kebenaran-kebenaran yang Paulus ajarkan kepada jemaat di Korintus juga relevan bagi jemaat masa kini.

Salah satu kebenaran yang ditekankan Paulus kepada jemaat di Korintus adalah bahwa orang percaya disebut sebagai Bait Allah. Dari sekian banyak surat Paulus, surat 1 Korintus merupakan surat yang paling banyak menggunakan istilah Bait Allah. Rasul Paulus pasti memiliki tujuan tersendiri dalam menggunakan istilah ini. Dengan kata lain, pasti ada makna yang terkandung dalam istilah tersebut yang penting untuk dipahami oleh para pengikut Kristus.

Berdasarkan alasan tersebut di atas, penulis mengangkat judul "Makna Bait Allah dalam 1 Korintus 3:16-17 dan Implikasinya Bagi Orang Percaya Masa Kini" dengan harapan bahwa melalui penelitian ini orangorang Kristen dapat memiliki pemahaman yang benar dan memadai sehingga mereka dapat menjadi pengikut Kristus yang setia, yang membangun gereja dalam satu kasih, satu iman dan satu pengharapan.

\section{Masalah Pokok}

Berdasarkan latar belakang di atas, pokok permasalahan yang coba untuk dijawab dalam penulisan karya ilmiah ini adalah:

Pertama, Mencari bagaimana pengertian tentang orang percaya adalah Bait Allah menurut 1 Korintus 3:16-17.

Kedua, Bagaimana implikasi orang percaya sebagai Bait Allah dalam konteks masa kini, sehingga orang percaya tidak membinasakannya seperti yang dimaksud dalam 1 Korintus 3:17.

\section{Tujuan Penulisan}

Tujuan-tujuan yang ingin dicapai dari penulisan ini: Pertama, untuk mengetahui pengertian yang benar tentang konsep orang percaya adalah bait Allah seperti yang dijelaskan dalam 1 Korintus 3:16-17.

Kedua, untuk memberikan gambaran implikasi makna Bait Allah dalam kehidupan orang percaya masa kini.

\footnotetext{
${ }^{5}$ John Drane, Memahami Perjanjian Baru—Pengantar Historis Teologis (Jakarta: BPK Gunung Mulia, 2009), 336.
} 


\section{Manfaat Penulisan}

Dengan mengetahui pengertian yang benar tenang konsep orang percaya adalah bait Allah, maka diharapkan penulisan karya ilmiah ini dapat memberi manfaat:

Pertama, terjadinya perubahan konsep hidup orang percaya, baik secara pribadi, maupun sebagai komunitas yang dapat berdampak pada perubahan sikap umat manusia yang lebih menghargai keberadaan dirinya sebagai Bait Allah. Kedua, hasil penelitian dari karya ilmiah ini diharapkan dapat menambah khazanah pengetahuan teologi, khususnya bidang kajian teologi biblika Perjanjian Baru.

\section{Metode Penelitian}

Sesuai dengan materi yang diteliti, maka metode penelitian yang digunakan adalah metode penelitian literatur dengan menggunakan teknik hermeneutika eksegesis yang bersumber dari buku-buku maupun media elektronik (internet).

\section{MAKNA BAIT ALLAH: EKSEGESE 1 KORINTUS 3:16-17}

\section{LatarBelakang Terminologi}

\section{Terminologi Bait Allah}

Setiap agama atau bentuk kepercayaan, pasti memiliki suatu tempat tertentu yang dijadikan tempat khusus untuk pemujaan dan penyembahan kepada oknum yang dipercayai itu. Istilah yang paling umum dikenal untuk tempat semacam ini adalah kuil. Kuil merupakan tempat pemujaan kepada yang ilahi, sebagai tempat kediaman ilah di bumi. ${ }^{6}$

Bait Allah merupakan tempat yang tidak asing dalam kehidupan dan peribadahan bangsa Israel. Bait Allah selaku tempat religius memiliki makna dan nilai tersendiri dalam Yudaisme. Orang-orang Yahudi sangat menghormati Bait Allah, karena disanalah pusat segala upacara religius dilakukan. Dalam bahasa Ibrani, Bait Allah dikenal היכַלירוּוה (heykal-YHWH).

${ }^{6}$ Philip J. King dan Lawrence E. Stager, Kehidupan Orang Israel Alkitabiah (Jakarta: BPK Gunung Mulia, 2001), 377. 
Menurut James Strong, secara harfiah kata heykal berarti a large public of building, such as a place or temple. Akar kata dari kata ini adalah yakol yang diadaptasi dalam perspektif kapasitas. ${ }^{7}$ Atas dasar inilah maka kata heykal ini digunakan secara umum untuk menunjuk bangunan yang luas dan besar, seperti Bait Allah.

Kata heykal menjadi spesifik penggunaannya ditentukan oleh frasa (kata) yang digandengkan dengan kata tersebut dan konteks dimana kata tersebut digunakan. Jika kata yang digandengkan dengan kata ini adalah YHWH, maka heykal sudah pasti berarti Bait Allah (misalnya dalam Ez. 3:10). Selain itu kata "kudus" juga merujuk kepada hal yang sama (misalnya dalam Mzm. 79:1), dan sama halnya jika kata heykal ini digunakan dengan definite article (misalnya dalam Yes. 6:1; Yeh. 41) pasti mengacu kepada Bait Allah di Yerusalem. Bait Suci merupakan istilah yang digunakan sejajar dengan Bait Allah, dan oleh karena itu, Bait Suci mengacu kepada hal yang sama yaitu Bait Allah. Dalam penggunaan di luar ini, heykal digunakan juga untuk menunjuk istana raja (misalnya dalam 1 Raj. 21:1), ataupun bangunan istana (misalnya dalam Maz. 144:12).

Selain heykal, kata lain yang juga dipakai untuk menunjuk hal sama adalah (bayit). Bayit secara harfiah berarti rumah, tempat kediaman. Seperti halnya kata heykal, kata bayit pun digunakan secara luas, menunjuk kepada bagunan rumah permanen, tempat kediaman atau tempat tinggal ataupun ruangan (dari sebuah rumah). Bayit mengacu kepada Rumah Allah hanya ketika kata bayit digandengkan dengan kata ALLAH (misalnya dalam Kel. 23:19). ${ }^{8}$ Dalam konteks ini, Rumah Allah sama maksudnya dengan Bait Allah.

Dua kata Yunani yang diterjemahkan bait suci dalam Perjanjian Baru adalah kata voòs (naos) dan i€póv (hieron). Hieron merupakan kata neuter dari kata hieros yang digunakan sebagai kata benda yang menunjuk pada suatu tempat yang sakral, atau sebuah kuil (Kis. 19:27). Dalam Markus 1l:1l, hieron digunakan untuk menunjuk Bait Suci secara keseluruhan dengan bagian-bagian (ruangan-ruangannya). Penggunaan yang demikian menyatakan bahwa hieron adalah kata yang menggambarkan keseluruhan Bait Suci secara lengkap, termasuk

\footnotetext{
${ }^{7}$ James Strong, Strong's Exhaustive Concordance of the Bible (USA: Thomas Nelson Publishers, 1984), s.v. "heykal"

${ }^{8}$ W. E. Vine, Vine's Expository Dictionary of Biblical Words s.v. "House" dalam PC Study
} 
kumpulan bangunan-bangunan yang semuanya membentuk Bait Suci. Naos adalah kata khusus yang digunakan untuk menunjuk tempat kudus yang ada dalam sebuah bait suci atau kuil. Naos berasal dari akar kata $\nu \alpha i \omega$ yang berarti to dwell. Bagi orang Yahudi, naos ini adalah ruang kudus, yang tidak sembarang orang dapat masuk ke dalamnya, kecuali imam yang bertugas (lih. Luk. 1:9,21-22). Di dalam naos inilah dewa (atau patung) yang disembah berdiam (Kis. 17:24). Septuaginta (LXX) menterjemahkan kata היכַל dengan kata naos.

\section{Penggunaan Kata Bait Allah Dalam Perjanjian Baru}

Sebagai mana telah diuraikan di atas, dalam Perjanjian Baru, ada dua kata yang diterjemahkan Bait Allah atau Bait Suci, yaitu hieron dan naos. Kata yang memiliki makna atau maksud yang sama namun agak jarang dipakai adalah topos hagios (= tempat kudus - Mat.24:15; Yoh.1l:48) dan to hagion / ta hagia (= yang kudus - Ibr. 8:2). Kata lain yang paling sering digunakan (lebih dari 50 kali penggunaan) dengan maksud atau

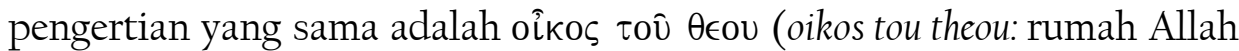
- Mat. 12:4). Pembahasan pada bagian ini akan difokuskan pada kata naos saja.

Dalam Perjanjian Baru, kata naos lebih sering digunakan dalam arti metafora. Hal ini dapat dilihat dalam Markus 14:58;15:29 (dan perikopperikop yang sejajar dalam Matius, Lukas dan Yohanes), dimana kata ini digunakan dalam arti kiasan, mengacu kepada makna rohani akan kematian dan kebangkitan Yesus. Mungkin hanya dalam Matius 25:5, Lukas 1:9, dan Yohanes 2:20 (dan perikop-perikop yang sejajar) kata naos digunakan dengan maksud literal yaitu menunjuk kepada ruang kudus dalam bangunan Bait Allah. Dalam terjemahan, naos dapat diterjemahkan Bait Allah atau Bait Suci, (tergantung bentuk genetive kata yang digandengkan) tetapi maksudnya sama.

Dari antara surat-surat kiriman, surat-surat Pauluslah yang menggunakan kata naos dan juga kitab Wahyu. Yang unik, surat-surat Paulus pun tidak semua menggunakan kata ini. Hanya surat-surat Korintuslah yang menggunakan kata ini. Penggunaannya pun selalu dalam arti kiasan. Memang jika diperhatikan dari latar belakang Paulus, ia pasti sudah sangat mengenal Bait Allah dengan baik. Oleh sebab itu, tidaklah mengherankan bahwa Paulus dapat membuat kiasan atau analogi yang baik menggunakan istilah bait Allah untuk mengajarkan suatu kebenaran yang mendasar dalam iman Kristen. 


\section{Latar Belakang Konteks 1 Korintus 3:1-23}

Jika diperhatikan dengan cermat, apa yang diuraikan dalam perikop ini sangat dekat berkaitan dengan apa yang diuraikan dalam pasal 1:10-17. Pokok yang dibicarakan hampir sama, yaitu mengenai perpecahan dalam jemaat. Penyebab perpecahan itu adalah faksionalisme. Faksionalisme adalah sikap menonjolkan diri dengan cara-cara oportunistis atau dengan cara mendorong perpecahan di dalam kelompoknya. ${ }^{9}$ Perbedaan pandangan di dalam jemaat dijadikan sebagai suatu persaingan yang merasa kelompoknya lebih benar daripada kelompok lain. Akhirnya persaingan ini menimbulkan keangkuhan kelompok. Keangkuhan ini akan bertumbuh menjadi kebencian kepada kelompok lain. Setiap kelompok merasa lebih baik daripada yang lainnya. J. Knox Chamblin mengatakan bahwa keangkuhan selalu berarti perseteruan, bukan hanya kepada manusia tetapi juga terhadap Allah. ${ }^{10}$ Dari hal ini jelaslah bahwa masalah di Korintus bukanlah ketidakmantapan jemaat karena masalah yang muncul dari lingkungannya tetapi karena orang-orang di dalam jemaat itu sendiri yang menyebabkan ketidakmantapan. ${ }^{11}$

Jemaat Korintus adalah jemaat yang sangat beruntung, karena dilayani oleh beberapa pemberita injil, yang membuat mereka semakin dewasa dan bisa bertumbuh. Mereka menggunakan hikmat duniawi (1 Kor 1:18-2:16), menilai pemimpin pemberita Injil yang sudah melayani dan akhirnya menuju kepada pilih kasih yang saling dipertentangkan. ${ }^{12}$ Warren Wiersbe mengatakan, "Jemaat Korintus membangun jemaatnya dengan hikmat manusia yaitu hikmat dunia, yang seharusnya bersandar pada hikmat Allah, yaitu firman-Nya." ${ }^{13}$ Semua pandangan dan sikap yang tidak sesuai dengan kebenaran ini telah menimbulkan berbagai perselisihan dan perpecahan dalam jemaat Korintus. Dengan demikian, menjadi jelaslah bahwa di jemaat Korintus:

${ }^{9}$ Ebta Setiawan, Kamus Besar Bahasa Indonesia Offline, versi 1.l. s.v. "faksi"

${ }^{10}$ J.Knox Chamblin, Paulus dan Diri: Ajaran Rasuli bagi Keutuhan Pribadi (Surabaya: Momentum, 2011), 116.

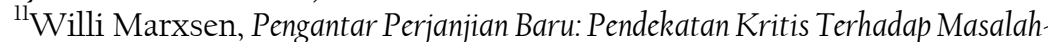
Masalahnya (Jakarta: BPK Gunung Mulia, 2012), 82.

${ }^{12}$ Russel P. Spittler, Pertama dan Kedua Korintus (Malang: Gandum Mas,. 1977), 27.

${ }^{13}$ Warren W. Wiersbe, Hikmat di dalam Kristus - Tafsiran 1 Korintus (Bandung: Yayasan Kalam Hidup, 1983), 54. 
Kekhususan kepercayaan Kristen, ungkapan, ibadah, dan moralitas menunjukkan tekanan-tekanan dari faktor-faktor lingkungan dan kebudayaan yang berbeda di suatu kota kafir yang makmur, yang dihubungkan baik dengan Yunani dan dunia Timur, di dalam suatu jemaat yang meliputi berbagai golongan dan latar belakang keagamaan serta tingkatan dalam pertumbuhan Kristen. Keadaannya dijadikan berbelit-belit oleh ajaran-ajaran Kristen yg hanya dimengerti setengah-setengah, dilayankan dengan lagak kecakapan berpidato, dan pemakaian slogan-slogan dengan tak bertanggung jawab, seperti 'pengetahuan' (1 Korintus 8:1) dan 'kebebasan' (1 Korintus 8:9). Dan musuh yg senantiasa tersedia dalam bentuk khusus di Korintus adalah dunia, daging, dan si jahat. $^{14}$

Paulus mengingatkan kepada Jemaat Korintus, bahwa hikmat Allah yang terpenting untuk mengenal Allah. Jangan menggunakan hikmat manusia untuk mengenal Allah. Jemaat Korintus meninggikan pemimpin jemaat berdasarkan hikmat manusianya, sehingga lebih mementingkan pemimpinnya daripada inti ajaran akan Salib. Pandangan yang saling mengunggulkan pemimpinnya inilah yang membuat jemaat menjadi terpecah, karena memegahkan diri di hadapan Allah (1:30). Jemaat Korintus memakai hikmatnya yang mengantar kepada keangkuhan dan menyediakan dasar persaingan, tipuan palsu, dan menuju kehancuran. ${ }^{15}$

Karena situasi jemaat di Korintus kurang harmonis, seperti yang digambarkan di atas, maka Rasul Paulus dalam pasal 3 ini menuliskan kebenaran-kebenaran yang penting untuk dipahami oleh jemaat Korintus agar jemaat tersebut dapat menjadi jemaat yang dewasa. Dalam pasal 3 surat ini, dengan jelas rasul Paulus menunjukkan bahwa akibat sikap faksionalisme dan keangkuhan mereka, maka timbul perselisihan dan perpecahan dalam jemaat itu. Rasul Paulus menyebut sikap yang demikian sebagai sikap manusia duniawi yang tidak mau dewasa di dalam Kristus (3:3). Untuk menyatakan hal ini, Paulus menggunakan

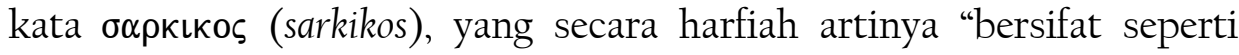

\footnotetext{
${ }^{14}$ Ensiklopedia Alkitab Masa Kini, s.v. "Surat-surat Korintus"

${ }^{15}$ J. Knox Chamblin, Paulus dan Diri: Ajaran Rasuli bagi Keutuhan Pribadi (Surabaya: Momentum, 2011), 123.
} 
daging", yang sama dengan "menurut daging" (Roma 8:4). Dibalik kata ini terdapat pengertian sifat bandel. ${ }^{16}$

Sikap jemaat di Korintus yang demikian membuat Paulus merasa penting untuk mengajarkan kepada mereka bahwa Kristuslah yang memiliki segalanya, baik jemaat maupun para pelayan jemaat. Oleh sebab itu dalam ayat 5 sampai 9, Paulus memakai metafora ladang dan pekerja, dimana jemaat di Korintus adalah ladang Allah, sedangkan Paulus dan semua orang yang melayani jemaat itu adalah kawan sekerja Allah.

Selain metafora ladang dan pekerja, Paulus juga memakai metafora bangunan Allah. Dalam ayat 9b hingga ayat 23, Paulus menarasikan metafora itu dengan sangat proporsional. Dasar dari bangunan itu adalah Kristus (3:11). Paulus - yang menyebut dirinya sebagai seorang ahli bangunan telah meletakkan dasarnya, dan orang lain (Apolos, Kefas) membangun terus diatasnya. Oleh sebab itu, setiap orang yang membangun diatas bagunan itu (yaitu jemaat Allah) harus memperhatikan bagaimana ia membangun, karena pekerjaan setiap orang sekali kelak akan diuji. Jika pekerjaan orang itu tahan uji, maka ia akan mendapat upah (3:14) tetapi jika pekerjaannya terbakar, ia akan menderita kerugian (3:15a). Dalam metafora bangunan dan orang yang membangun ini, Paulus menujukan pengajarannya bukan kepada anggota jemaat saja, tetapi juga kepada mereka yang melayani jemaat itu.

Ayat 16 - 17 merupakan ayat kunci untuk pasal 3 ini. Paulus menyatakan bahwa jemaat Korintus sebagai komunitas adalah Bait Allah dan bahwa Roh Allah berdiam di tengah-tengah jemaat. Oleh sebab itu tidak, bait Allah tidak boleh dibinasakan, sebab bait Allah itu kudus, karena Allah berdiam di sana. Sebagai bait Allah, jemaat Korintus seharusnya menghindari sikap hidup duniawi yakni kesombongan, perselisihan, percabulan, dan hal-hal lain yang mengancam persatuan dan kesatuan jemaat. Nasihat dalam ayat-ayat ini dipertegas kembali dalam pasal 6:19-20.

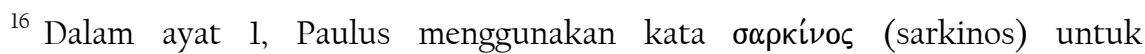
menyatakan manusia duniawi. Sarkinos secara harfiah berarti terbuat dari daging, yang didalamnya terkandung pengertian kelemahan (Mat.26:4l). Dalam konteks ayat 1 ini dapat dipahami bahwa Paulus memang menganggap jemaat di Korintus sebagai jemaat yang masih belum dewasa ketika ia melayani jemaat tersebut sebelumnya. Lih. Charles F. Pfeifer dan Everett F. Horisson (ed.), Tafsiran Alkitab Wycliff Vol.3 (Malang: Gandum Mas, 2001), 610 . 
Dalam bagian selanjutnya yaitu pasal 4:1-5, Paulus menyatakan bahwa Tuhanlah yang menjadi hakim atas setiap pekerja-Nya bahwa kepada Dia-lah semua pekerja akan mempertanggungjawabkan pekerjaan mereka. Tuhan adalah satu-satunya hakim yang menguji setiap pekerjaan, yang akan menghakimi seadil-adilnya. ${ }^{17}$ Ketika Tuhan menghakimi, maka "Ia akan menerangi, juga apa yang tersembunyi dalam kegelapan, dan Ia akan memperlihatkan apa yang direncanakan didalam hati. Maka tiap-tiap orang akan menerima pujian dari Allah" (4:5).

Akhirnya, dalam pasal 4:6-21, Rasul Paulus kembali menekankan kepada jemaat di Korintus agar mereka tidak "menyombongkan diri dengan jalan mengutamakan yang satu dari pada yang lain" (4:6). Nasihat pada bagian ini paralel dengan apa yang telah disinggung dalam pasal 3:18-21, di mana Paulus menyatakan hal sama, agar "jangan ada orang yang menipu diri sendiri, yang menyangka dirinya berhikmat menurut dunia ini" (3:18) dan "jangan ada orang yang memegahkan dirinya atas manusia" (3:21). Pertumbuhan rohani yang dewasa dan persatuan dan kesatuan jemaat hanya dapat dicapai dengan menjauhkan hal-hal semacam ini.

\section{Makna Bait Allah Dalam 1 Korintus 3:16-17}

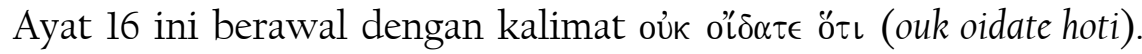
Kata oủk adalah kata yang berarti tidak, bukan, jangan. Ketika kata ini digunakan dalam bentuk pertanyaan, maka pertanyaan yang diajukan mengharapkan jawaban positif. ${ }^{18}$ Kata ini biasa digunakan sebagai pertanyaan retoris, yang jawabannya adalah kepastian atau pernyataan. ${ }^{19}$

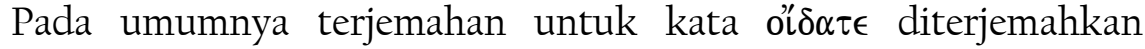
tunggal, kecuali dalam terjemahan CEV. Sebagaimana telah disebutkan, kata ini sebenarnya adalah kata kerja dengan bentuk orang kedua jamak. Dalam terjemahan CEV hal ini nampak jelas, tetapi disisi lain, terjemahan CEV memiliki kekurangan, karena kata oủk sepertinya tidak

\footnotetext{
${ }^{17}$ Adina Chapman, Pengantar Perjanjian Baru (Bandung: Yayasan Kalam Hidup, 2004), 65.

${ }^{18}$ Barclay M. Newman Jr, Kamus Yunani - Indonesia (Jakarta: BPK Gunung Mulia, 1991), 120.

${ }^{19}$ Paul Ellingworth dan Howard Hatton, Surat Paulus yang Pertama kepada Jemaat di Korintus (Jakarta: LAI, 2010), 88. Dalam terjemahan TB LAI frasa ini diterjemahkan: "tidak tahukah kamu.." Dalam terjemahan FAYH berbunyi: "Tidakkah Saudara menyadari bahwa...". Sementara dalam terjemahan BIS berbunyi; "Tahukah Saudara", CEV berbunyi: All of you know that..." Sedangkan dalam terjemahan NKJV menerjemahkan: "Do you not know that..."
} 
mendapat perhatian dalam terjemahan ini, dan hal sama terlihat dalam terjemahan BIS.

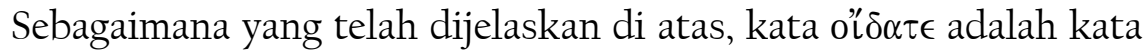
kerja orang kedua plural perfect active indicative. ${ }^{20}$ Bentuk jamak yang digunakan dalam bagian ini menunjukkan bahwa yang dimaksud dalam ayat ini bukan menunjuk kepada perseorang, tetapi kepada banyak orang. Bentuk perfek yang digunakan dalam kata ini menyatakan bahwa tindakan "mengetahui" telah rampung, selesai atau tercapai, yang dibuktikan dengan suatu kondisi atau akibat atau dampak yang masih terasa hingga pada masa kini. ${ }^{21}$

Dengan demikian, frasa awal dalam ayat 16 ini merupakan dasar penting yang patut dipahami dalam kaitannya dengan kalimat-kalimat berikutnya, bahkan ayat selengkapnya, yaitu ayat 16. Dalam kalimatkalimat berikutnya hingga ayat 17, Paulus menegaskan kepada jemaat di Korintus empat kebenaran penting berkaitan dengan kehidupan Kristen sebagai komunitas Allah dengan menggunakan metafora Bait Allah, bahwa mereka adalah Bait Allah, bahwa Bait Allah merupakan tempat kediaman Allah, bahwa Bait Allah itu tidak boleh dibinasakan dan Bait Allah itu kudus. Keempat kebenaran ini adalah kebenaran yang mendasar (tidak dapat dibantah, harus diterima secara positif), dan patut dipahami dengan baik sehingga dapat memberi dampak yang berkelanjutan dalam realitas hidup sehari-hari. Berikut ini pembahasan keempat poin tersebut secara spesifik.

Bait Allah adalah Kumpulan Orang Percaya (ay. 16b, 17d)

Penegasan Paulus kepada jemaat di Korintus bahwa mereka adalah

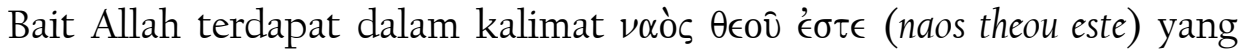
secara literal berarti kamu (sekalian) adalah bait Allah.

Penggunaan bentuk "kamu" dalam bentuk jamak (empat kali bentuk "kamu" jamak dalam ayat 16-17) dalam kalimat ini mengindikasikan bahwa yang dimaksud atau yang menjadi tujuan penekanan Paulus adalah jemaat di Korintus secara keseluruhan. Ini berarti Rasul Paulus hendak menyatakan bahwa jemaat (sebagai kumpulan orang percaya) sesungguhnya adalah bait Allah. Dalam bagian lain, yaitu pasal 6:19, Rasul Paulus juga menggunakan pola yang sama, dimana ia menggunakan kata "kamu" dalam bentuk jamak. Walau ada

\footnotetext{
${ }^{20}$ Hasan Sutanto, Perjanjian Baru Interlinear Yunani - Indonesia dan Konkordansi Perjanjian Baru (PBIK) jilid I (Jakarta: Lembaga Alkitab Indonesia, 2003), 893.

${ }^{21}$ Ferdinand K. Suawa, Memahami Gramatika Dasar Bahasa Yunani Koine (Bandung: Yayasan Kalam Hidup, 2009), 164.
} 
penafsir yang berpandangan bahwa ayat-ayat ini mengacu kepada orang percaya secara individual, ${ }^{22}$ tetapi lebih baik ayat ini (3:16-17) dipahami dalam bentuk gramatikalnya dimana yang dimaksudkannya adalah orang percaya secara kolektif. ${ }^{23}$ Pengenalan terhadap bahasa Yunani dari Paulus ini menunjukkan bahwa disini Paulus tidak memikirkan individu-individu Kristen sebagai Bait Allah, melainkan persekutuan orang beriman di Korintus. ${ }^{24}$

Tidak dapat dipungkiri bahwa ada hubungan yang erat antara orang percaya secara personal dengan orang percaya secara kolektif. Tidak mungkin ada jemaat (sebagai suatu perkumpulan orang yang percaya), jika tidak ada pribadi-pribadi yang sepakat untuk berkumpul bersama sehingga menjadi sebuah kumpulan kolektif. ${ }^{25}$ Donald Guthrie juga mengatakan bahwa, "keseluruhan orang percaya sebagai tempat kediaman Allah, juga berarti setiap orang Kristen adalah rumah Allah." ${ }^{26}$

Mengingat surat Korintus ditujukan kepada jemaat secara umum, maka lebih baik (khususnya mengenai pengajaran dalam pasal 3:16-17 ini) dipahami dalam konteks ini. Tentu saja tidak dapat disangkal bahwa pokok yang diajarkan secara kolektif mempunyai implikasi personal yang sangat signifikan.

Dalam ayat 17 bagian akhir, penegasan mengenai jemaat sebagai

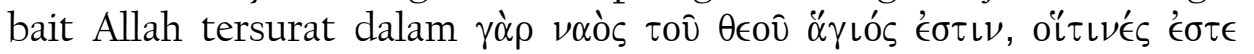

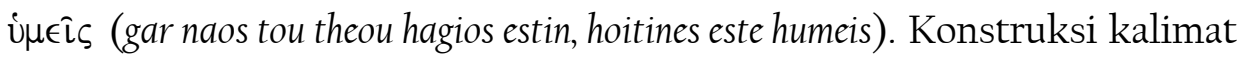
ini seluruhnya berbentuk jamak, menunjuk kepada orang percaya secara

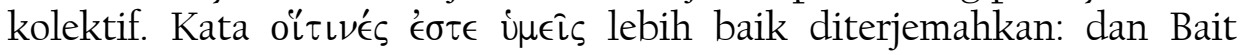
Allah itu ialah kalian (kamu sekalian).

\footnotetext{
${ }^{22}$ Lihat David Ibrahim, Pelajaran Surat 1 Korintus (Jakarta: Mimery Press, 1999), 53. Hal yang sama dikatakan oleh Val Boyle, tersedia di www.bible-truths-revealed.com

${ }^{23}$ David E. Hall (ed), Adult Teaching Guide: 1 Corinthias (Mineapolis: Evangelical Free Church, 1989), 36. Tafsiran yang sama dikemukakan oleh Leon Morris, The First Epistle of Paul to The Corinthians (Michigan: Wm. B. Eerdmans Publishing Company, 1979), 69. Lihat juga, Warren W. Wiersbe, Hikmat dalam Kristus (Bandung: Yayasan Kalam Hidup, 1983), 52.

${ }^{24}$ Manfred T. Brauch, Ucapan Paulus yang Sulit (Malang: Seminary Alkitab Asia Tenggara, 1999), 80 2012), 484

${ }^{25}$ Tafsiran Alkitab Masa Kini 3 (Jakarta: Yayasan Komunikasi Bina Kasih/OMF,

${ }^{26}$ Donald Guthrie, Teologi Perjanjian Baru 3 (Jakarta: BPK Gunung Mulia, 1993), 74.
} 
Berdasarkan uraian di atas, jelaslah bahwa bait Allah yang dimaksudkan dalam bagian ini adalah jemaat sebagai kumpulan orang percaya. Pengenaan makna ini menguatkan kebenaran yang jelas terlihat dalam penggunaan kata ekklesia yaitu menunjuk kepada kesatuan gereja dalam keanekaragamannya. ${ }^{27}$

\section{Bait Allah Adalah Tempat Kediaman Allah (Ay.16c)}

Pengajaran Paulus tentang bait Allah dalam ayat 16c ini adalah bahwa bait Allah merupakan tempat kediaman Allah. Hal ini terlihat

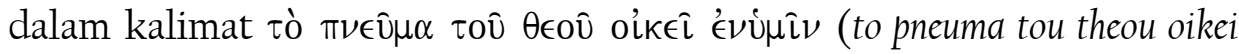
en humin). Oikei adalah kata kerja present aktif indikatif untuk orang ketiga tunggal. ${ }^{28}$

Dalam terjemahan LAI, ayat ini berbunyi; "Roh Allah diam di dalam kamu," dalam terjemahan FAYH; "Roh Allah hidup diantara saudara di dalam rumah-Nya," dalam terjemahan BIS; "Roh Allah tinggal di dalam kalian," dalam terjemahan CEV; "His Spirit lives in you", dalam terjemahan NKJV; "The Spirit of God dwells in you." Dari keempat terjemahan ini, terjemahan BIS cukup baik, meskipun lebih baik menggunakan kata"berdiam" dari pada kata "tinggal" Berdasarkan ayat ini, jelaslah bahwa kumpulan orang percaya adalah habitation of God. ${ }^{29}$ Sebagaimana bangunan bait Allah merupakan lambang tempat kediaman Allah ditengah-tengah umat Israel, maka di dalam jemaat, Allah berdiam ditengah-tengah mereka. Jemaat adalah umat yang ditebus oleh Allah sendiri, sebagaimana Israel adalah umat yang dipilih Allah sendiri.

Makna dari frasa ini hanya dapat dipahami dengan baik jika frasa ini dikaitkan dengan frasa sebelumnya (Yunani: naos tou theou). David Peterson menyatakan bahwa:

The expression naos tou theou marks out the Corinthian church as the divine sanctuary where God's Spirit dwells. The imagery reflects the Old Testament idea that God was specially present in the midst of his people (e.g. Ex. 29:44-46; 33:14-16; Ps. 114:2). Prophecies about the restoration of Israel after the Babylonian exile included the promise of the gift of God's Spirit, as the means

\footnotetext{
${ }^{27}$ George Eldon Ladd, Teologi Perjanjian Baru, Jil. 2 (Bandung: Yayasan Kalam Hidup, 1999), 331.

${ }^{28}$ Hasan Sutanto, Perjanjian Baru Interlinear Yunani - Indonesia (Jakarta: Lembaga Alkitab Indonesia, 2003), 893.

${ }^{29}$ Spiros Zodhiates, Hebrew - Greek Keyword Study Bible, (Tennesse: AMG Publisher, 1990), s.v. "habitation of God."
} 
by which he would dwell in or among his people and bless them in a new way (e.g. Joel 2:28-32; Is. 44:3-5; Ezk. 36:27-28; 37:14). The hope of a new temple, which was another way of speaking about the ultimate renewal of God's people, finds expression in the reality of the Christian congregation! $!^{30}$

Sebagaimana pandangan di atas, dapatlah dikatakan bahwa Paulus mengadopsi gagasan dari PL dan mengenakannya dalam pengajaran mengenai bait Allah kepada jemaat Korintus, bahwa bait Allah adalah tempat kediaman Allah, sebuah perwujudan pengharapan yang baru tentang pemulihan umat Allah. Sehubungan dengan hal ini, Donald Guthrie menyatakan bahwa:

Hal ini bukan hanya memperlihatkan adanya perkembangan dalam pemikiran, yaitu menggantikan hal yang bersifat lahiriah dengan yang bersifat batiniah, tetapi juga memperlihatkan bahwa suatu bangunan yang khusus bagi kediaman Allah tidak dibutuhkan lagi. Betapa pun bernilainya tempat kediaman Allah bagi Israel, namun Jemaat Kristen tidak memerlukan suatu tempat seperti itu. Gagasan tentang bangunan betul-betul menjadi kiasan dan karena itu bersifat rohani. ${ }^{31}$

Dengan demikian, dalam konteks ini, kumpulan orang percaya dipandang sebagai tempat kediaman Allah. Allah tidak saja hadir dalam bangunan fisik, tetapi juga dalam komunitas (umat) yang dipilih-Nya. Akan tetapi, pandangan ini tidak boleh diartikan bahwa orang umat Allah tidak perlu lagi beribadah di dalam sebuah bangunan. Memang, kehadiran Allah lebih penting dari pada bangunan, tetapi Ia juga menghendaki agar umat-Nya beribadah kepada-Nya di suatu tempat yang dikhususkan bagi-Nya, yaitu gereja.

\section{Bait Allah Itu Harus Dipelihara (Ay. 17a)}

Sebagai tempat kediaman Allah, Bait Allah harus dipelihara dan bait Allah itu kudus. Penekanan rasul Paulus tentang kedua hal ini dikemukakan dalam ayat 17 ini. Dikatakan bahwa; "Jika ada orang yang membinasakan bait Allah, maka Allah akan membinasakan dia. Sebab bait Allah adalah kudus ...(LAI). “

\footnotetext{
${ }^{30}$ David Peterson, Engaging with God: A Biblical Theology of Worship (Illinois: Intervarsity Press, 1992), 201.

${ }^{31}$ Donald Guthrie, Teologi Perjanjian Baru, Jil. 3 (Jakarta: BPK Gunung Mulia, 1993), 75
} 
Kata $\phi \theta \in i ́ p \in \iota$ berasal dari kata $\phi \theta \in i ́ \rho \omega$ yang berarti, merusak, menghancurkan, menyesatkan, memperkosa. ${ }^{32}$ Dari definisi ini, dapat dikatakan bahwa kata ini juga secara harfiah mengandung makna merana, menyia-nyiakan, juga digunakan untuk menyatakan sesuatu yang dilayukan atau dipudarkan atau dilisutkan dengan berbagai cara dan secara figuratif digunakan untuk menyatakan sesuatu yang diruntuhkan melalui pengaruh moral.

Dengan demikian, jelaslah bahwa merusakkan bait Allah yaitu persekutuan orang-orang percaya adalah dengan mengajarkan ajaran sesat yang membuat jemaat berkanjang dalam kehidupan daging yang tidak memuliakan Allah. Para pengajar jemaat harus memperhatikan hal ini dengan serius karena mereka yang tugas dan tanggung dalam mengajar jemaat. Bahaya pengajar palsu yang bisa menyusup ke tengah jemaat dan akan merusak kehidupan berjemaat, bisa merusak umat-Nya, yang berarti melawan Kristus. ${ }^{33}$

Konsekuensi dari tindakan merusakkan bait Allah adalah "Allah

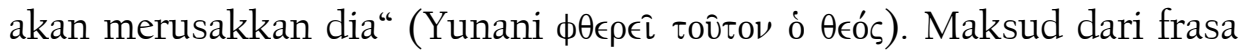
ini sulit diartikan. Leon Morris mengatakan bahwa The word is not specific and cannot be pressed to mean either annihilation or eternal torment. ${ }^{34}$ Penafsir lain berpendapat bahwa frasa "Allah akan membinasakan dia" berarti Allah akan mengambil bagiannya dari buku kehidupan atau ia tidak akan mendapat bagian dalam buku kehidupan. ${ }^{35}$ Dari berbagai tafsiran yang muncul, penulis lebih cenderung dengan tafsiran David E Hall, K. Riedel dan David Ibrahim yang menyatakan bahwa maksud dari bagian ini menunjukkan bahwa Allah tidak akan membiarkan orang yang melakukan tindakan semacam itu, Allah akan menghukum dan membuat perhitungan dengan mereka. ${ }^{36}$

\footnotetext{
${ }^{32}$ Barclay M. Newmann, Kamus Yunani - Indonesia (Jakarta: BPK Gunung Mulia, 1991), 183

${ }^{33}$ Billy Kristanto, Ajarlah Kami Bertumbuh : Refleksi atas Surat 1 Korintus (Surabaya: Momentum, 2011), 45.

${ }^{34}$ Leon Morris, Tyndale New Testament Commentaries: 1 Corinthians (Michigan: Wm. B. Eerdmans Publishing Company, 1985), 67.

${ }^{35}$ Adam Clarke, The New Testament Commentary and Critical Notes, Vol. V (Nashville: Abingdon Press, 1966), 205

${ }^{36}$ David Ibrahim, Pelajaran Surat 1 Korintus (Jakarta: Mimery Press, 1999), 54., dan

David E. Hall (ed), Adult Teaching Guide: 1 Corinthias (Mineapolis: Evangelical Free Church, 1989), 36. K Riedel, Surat Jang Pertama kepada Orang Korintus (Djakarta: BPK Gunung Mulia, 1955), 33
} 
Memerhatikan semua uraian di atas, maka dapat dikatakan bahwa Bait Allah harus dipelihara, tidak boleh dirusakkan atau dicemari dengan cara apapun. Barangsiapa merusakkan Bait Allah, Allah akan membuat perhitungan dengannya. Pemeliharaan bait Allah berkaitan pembangunannya, yaitu pembangunan rohani, dan hal ini dapat terjadi jika para pengajar jemaat sebagai rekan sekerja Allah (3:9) melakukannya dengan menjaga kemurnian pengajaran mereka. Orang yang dengan sengaja membuat bait Allah rusak akan berurusan dengan Allah sendiri karena adalah milik Kristus (3:23).

\section{Bait Allah Adalah Kudus (Ay.17c)}

Setelah Paulus mengungkapkan bahwa bait Allah adalah kumpulan orang percaya, bahwa bait Allah merupakan tempat kediaman dan kehadiran Allah, dan bahwa bait Allah tidak boleh dihancurkan, maka dalam pengajarannya di ayat yang ke 17c ini, Paulus menyatakan bahwa Bait Allah itu kudus. Dikatakan dalam terjemahan LAI "Sebab

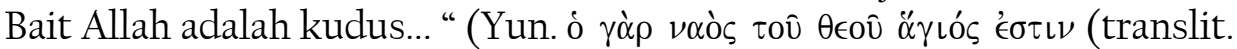
ho gar naos tou theou hagios estin).

Kata "kudus" yang dipakai dalam bagian ini adalah hagios. Kata ini juga berarti suci, murni, dipisahkan. ${ }^{37}$ Menurut Strong, kata ini berasal dari kata hagos yang berarti sesuatu yang dashyat (an awful thing). Hagios berarti sacred (physically, pure, morally blameless or religious, ceremonially, consecrated). ${ }^{38}$ Dari definisi-definisi tersebut, hagios berkaitan erat dengan keadaan yang suci, murni, terpisah, yang secara moral sempurna; tak bersalah atau bercacat cela.

Dalam PL, kata yang dipakai untuk "kudus" adalah קדש (qadosy). Dalam Ensiklopedi Alkitab Masa Kini Vol. I dikatakan bahwa qadosy dapat berarti 'terpisah' (dikhususkan) atau 'terpotong dari' digunakan terhadap keadaan terlepasnya seseorang atau suatu benda (supaya Tuhan dapat memakainya, dan dengan demikian terhadap keadaan orang atau obyek yang dilepas itu). Hagios mempunyai dasar pemikiran yg sama mengenai keterpisahan dan kesucian terhadap Allah. ${ }^{39}$

Kekudusan adalah karakteristik fundamental Allah, yang dalam kitab Yesaya 6:3 “... Kudus, kudus, kuduslah Tuhan semesta alam," pernyataan Serafim kepada nabi Yesaya, ungkapan kudus disebutkan

\footnotetext{
${ }^{37}$ David Ibrahim, Pelajaran Surat 1 Korintus, (Jakarta: Mimery Press, 1999), 54

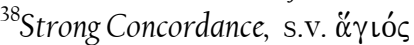

${ }^{39}$ Ensiklopedi Alkitab Masa Kini Vol. I, s.v. "kudus, kekudusan”
} 
tiga kali yang dalam bahasa Ibrani merupakan ungkapan superlatif yang berarti maha kudus. ${ }^{40}$

Sebagaimana bangunan Bait Allah kudus, maka kumpulan orang percaya yang kepadanya dikenakan sebutan bait Allah juga adalah kudus. Korelasi inilah yang ditunjukkan Paulus dalam ayat ini. Kekudusan bukan saja berkaitan dengan bendawi, tetapi juga menunjuk kepada umat Allah sejati yang dipelihara dan dilepaskan oleh Tuhan dari kefasikan dan penghakiman. Persekutuan orang kudus merupakan umat Allah yang sejati, Israel eskatalogis yang menerima janji Allah berkat keselamatan di dalam Kristus. ${ }^{41}$

Kekudusan berkaitan erat dengan kehadiran Allah. Sebagaimana kehadiran Allah di bait Allah menguduskan tempat itu dan mereka yang melayani di dalamnya, demikian pula kehadiran Allah di tengah-tengah kumpulan orang percaya. Matius 18:20 menyatakan, "Sebab di mana dua atau tiga orang berkumpul dalam nama-Ku, di situ Aku ada di tengahtengah mereka."

\section{IMPLIKASI MAKNA BAIT ALLAH DALAM KEHIDUPAN ORANG PERCAYA}

\section{Hidup dalam Kesatuan}

Bait Allah adalah kumpulan orang-orang percaya. Sebagai suatu kumpulan, maka didalamnya terdapat berbagai macam orang dengan latar belakang kehidupan, budaya, pendidikan, status sosial, bahkan karakter dan sifat yang berbeda-beda. Semua perbedaan semacam ini, dari satu sisi merupakan keunikan tersendiri bagi suatu perkumpulan, tetapi disisi lain juga bisa menjadi faktor utama yang memicu terjadinya perpecahan dalam perkumpulan tersebut.

Jemaat di Korintus adalah jemaat yang majemuk dalam berbagai hal. Dari Apa yang tertulis dalam surat ini, kemajemukan rupanya telah meruncing terjadinya pengelompokan yang berpotensi menimbulkan berbagai masalah dalam jemaat, yang kemudian mengancam kesatuan jemaat sebagai tubuh Kristus. Jika kesatuan jemaat tidak dapat dipertahankan, maka kebenaran akan sulit dinyatakan. Oleh sebab itu,

\footnotetext{
${ }^{40}$ Kamus Gambaran Alkitab, s.v. "kudus, kekudusan"

${ }^{41}$ Herman Ridderbos, Paulus: Pemikiran Utama Teologinya (Surabaya: Momentum, 2010), 349-350.
} 
perpecahan sedapat mungkin tidak boleh dibiarkan terjadi; walau harus diakui bahwa perbedaan adalah sesuatu yang tidak bisa dihindari. ${ }^{42}$

Salah satu faktor yang memicu terjadinya perpecahan adalah sikap favoritisme. Dalam jemaat di Korintus, ada jemaat yang mengagumi Paulus, ada yang mengagumi Apolos, Kefas dan Kristus. Memang tidak ada salahnya mengagumi pemimpin rohani atau hamba Tuhan tertentu, tetapi hal ini harus dalam porsi yang wajar. Namun, yang terjadi dalam jemaat di Korintus adalah kekaguman yang berlebihan. Billy Kristianto mengungkapkan bahwa:

Akan tetapi yang terjadi dalam jemaat Korintus bukanlah kekaguman biasa. Kekaguman yang tidak wajar ini akhirnya membawa semangat favoritisme yang kekanak-kanakan, dan inilah yang merusak gereja Tuhan. Ketika kita hanya mau mendengar hamba Tuhan tertentu kita sedang berpotensi untuk menjadi jemaat yang terpecah belah, seperti yang tertulis dalam surat ini. Ada aspek negatif ketika kita menunjukkan sikap favoritisme bukan hanya dalam hal kekaguman yang cenderung membawa kepada kultus individu, melainkan juga dalam kesempitan hati untuk tidak mau diajar oleh yang lain. ${ }^{4}$

Dari pernyataan di atas, dapat dikatakan bahwa untuk menjaga dan melestarikan kesatuan, sikap favoritisme yang berlebihan harus dihindari. Setiap orang yang adalah anggota Bait Allah (kumpulan orang percaya) harus menjaga dan memperhatikan diri supaya mereka tidak berlebihan mengagumi atau mengagungkan seseorang (dalam hal ini para pemimpin mereka atau hamba Tuhan yang melayani mereka). Dengan menjauhkan diri dari sikap favoritisme yang berlebihan semacam ini, maka pengkultusan terhadap pemimpin rohani atau hamba Tuhan tidak akan muncul. Setiap orang hendaknya memandang kepada Kristus saja yang adalah kepala, dan menjadikan Dia sebagai pusat segalagalanya.

Ancaman lain terhadap kesatuan jemaat sebagai kumpulan orang percaya adalah adanya sikap yang tidak benar terhadap karunia-karunia rohani. Kenyataan ini tidak saja dapat ditemui dalam surat 1 Korintus ini, tetapi juga dalam surat Efesus. Dalam surat-surat Paulus terlihat dengan

\footnotetext{
${ }^{42}$ Eka Darmaputera, Menyembah dalam Roh dan Kebenaran: Khotbah-Khotbah tentang Kehidupan Beribadah dan Bergereja yang Kontekstual (Jakarta: BPK Gunung Mulia, 2005), 177.

${ }^{43}$ Billy Kristianto, Ajarlah Kami Bertumbuh: Refleksi atas Surat 1 Korintus (Surabaya: Moementum, 2011), 9.
} 
jelas bahwa Allah memberi karunia-karunia rohani kepada anak-anakNya untuk kebaikan mereka walau pada kenyataannya karunia-karunia ini juga dijadikan alat perpecahan. Orang Kristen sepatutnya menyadari bahwa sifat gereja yang sesungguhnya adalah "Jemaat yang adalah tubuh-Nya" (Ef. 1:22-23). Semua orang percaya adalah anggota tubuh Kristus dimana setiap orang mempunyai tempat dan fungsi masingmasing (1 Kor. 12). Oleh karena itu, semua orang percaya bertanggung jawab untuk saling memerhatikan satu sama lain.

Kenyataan bahwa karunia rohani tidak diberikan kepada satu orang saja bisa saja menjadi fakor yang memicu terjadinya perselisihan dan perpecahan. Karena setiap orang memiliki karunia, maka kecenderungan untuk mengunggulkan karunia yang diperoleh dengan mudah terbentuk. Karunia yang satu dianggap lebih istimewa dan mulia dari pada karunia yang lain. Pada tingkat ini, karunia yang seharusnya dipakai untuk melengkapi, membangun dan melayani justru menjadi sarana untuk menonjolkan diri, yang kemudian memicu terjadinya perselisihan dan perpecahan. Karunia rohani tidak diberikan untuk kepentingan pribadi atau keuntungan pribadi, bukan juga untuk menyatakan bahwa seseorang sudah lebih dewasa secara rohani atau telah mencapai tahap kerohanian yang lebih tinggi. ${ }^{44}$ Karunia rohani patut dilihat dalam perspektif Allah, Sang Pemberi karunia, bukan berdasarkan hikmat duniawi. Hikmat duniawi cenderung membawa kepada keegoisan dan penonjolan diri, tetapi hikmat surgawi menuntun kepada kerendahan hati karena Kristus adalah standarnya. Kristus adalah kekuatan kekuatan Allah dan hikmat Allah (1 Kor. 1:24). Isu kepemimpinan dan karunia rohani masih merupakan isu yang sering mendominasi munculnya masalah perpecahan gereja. Kenyataan ini mengindikasikan bahwa kesatuan orang-orang percaya masih merupakan hal yang patut diperjuangkan dan diusahakan dengan sungguh-sungguh. Hal ini mungkin karena tidak adanya sikap sehati sepikir.

Keanekaragaman tidak dapat dihapuskan dari persekutuan orangorang percaya. Bait Allah yang adalah kumpulan orang-orang percaya perlu memahami dan memaknai keanekaragaman dalam berbagai aspek itu sebagai suatu sarana untuk saling memperlengkapi. Ketika orangorang yang beranekaragam itu saling memperlengkapi, melayani dan membangun dalam kasih, Kristus dinyatakan dengan cara yang indah. Panggilan Kristiani ialah hidup dalam persatuan. Komunitas Kristiani

${ }^{44}$ Kristianto, Ajarlah Kami Bertumbuh: Refleksi atas Surat 1 Korintus, 175. 
yang bersatu dalam suasana saling mengasihi adalah tempat nyata dimana Yesus membuat diri-Nya dapat dilihat. ${ }^{45}$

\section{Hidup dalam Penyembahan}

Ketika Allah menyatakan diri-Nya, maka ada penyembahan. Dimana Allah hadir, disitulah ciptaan-Nya patut menyembah kepadaNya (bnd. Kej. 12:8). Allah bersemayam di surga, di sanalah para malaikat menyembah-Nya. Ketika Allah hadir di Bait Suci, disanalah umat-Nya menyembah Dia. Kehadiran Allah merupakan alasan dan dasar penyembahan. Allah adalah Allah yang mulia dan berkuasa, dan karena sifat dan hakikat-Nya, Ia layak menerima semua bakti dan sembah dari ciptaan-Nya. James Montgomery Boice menyatakan bahwa "satusatunya penyembahan yang benar dan dapat diterima adalah penyembahan yang diarahkan kepada Allah. Jika penyembahan tidak diarahkan kepada Allah, itu bukan penyembahan yang benar, tidak peduli betapa sopan atau berkesannya seremoni itu." ${ }^{46}$

Alkitab sendiri tidak memberikan definisi tentang penyembahan. Penyembahan kepada Tuhan tidak didefinisikan dimanapun di dalam Alkitab. ${ }^{47}$ Akan tetapi kata "penyembahan", "menyembah", dan "penyembah" dicatat lebih dari 270 kali dalam Alkitab. ${ }^{48}$ Penggunaan kata menyembah dalam Alkitab biasanya mengacu kepada sikap sujud dengan penuh hormat dan pemujaan.

Dalam Perjanjian Baru, ada tiga kata yang dipakai untuk penyembahan, yaitu latreuo, sebomai, dan proskuneo. Latreuo berarti menyembah di muka umum dan digunakan sebanyak empat kali dalam PB. Sebomai digunakan sebanyak delapan kali, memberikan gagasan tentang rasa takut atau terpana karena kagum. Proskuneo digunakan sebanyak lima puluh sembilan kali. ${ }^{49}$

\footnotetext{
${ }^{45}$ Francis Xavier Kardinal Nguyen Van Thuan, Kesaksian Pengharapan (Jakarta: Yayasan Obor, 2002), 168. 2011), 678 .

${ }^{46}$ James Montgomery Boice, Dasar-Dasar Iman Kristen (Surabaya: Momentum,

${ }^{47}$ Seperti yang dikutip dari Vine Expository Dictionary of Old and New Testament Word oleh Joyce Meyer, The Power of Simple Prayer, (Jakarta: Immanuel, 2012), 110.

${ }^{48}$ Judson Cornwall, Let Us Worship: Panggilan untuk Menjadi Penyembah yang Benar (Yogyakarta: Yayasan Andi, 2009), 19.

${ }^{49}$ Judson Cornwall, Let Us Worship: Panggilan untuk Menjadi Penyembah yang Benar (Yogyakarta: Yayasan Andi, 2009), 55.
} 
Sebagai Bait Allah, orang-orang Kristen patut hidup dalam penyembahan yang sejati. Orang Kristen menyembah Allah bukan saja dalam ibadah Mingguan atau ibadah pribadi yang biasa dilakukan, tetapi mereka sepatutnya menyembah Allah dalam keseluruhan aspek kehidupan mereka. Hidup dalam penyembahan berarti hidup dalam kesungguhan untuk mengenal dan menanggapi karakter dan kehendak Allah yang dibarengi dengan sikap penyerahan diri yang terus-menerus kepada-Nya. Penyembahan harus lahir dari lubuk hati yang terdalam, yang diwujudkan dalam sikap atau tindakan yang menghormati dan meninggikan Dia.

Akhirnya, setiap orang percaya seharusnya menjadi penyembah Allah yang sejati. John MacArthur menegaskan bahwa penyembahan bukanlah masalah pilihan. Dalam Mat. 4:10, ketika menanggapi pencobaan iblis, Yesus mengutip Ul. 6:13, "Engkau harus menyembah Tuhan Allahmu dan hanya kepada Dia sajalah engkau berbakti!". Dengan berkata demikian kepada iblis, Ia memerintahkan kepada setiap makhluk yang telah diciptakan. Semua bertanggung jawab menyembah Allah. ${ }^{50}$ Penyembahan sejati adalah tanggapan kepada Allah yang tetap ada dimanapun juga, kapan saja, entah hal-hal religius ada atau tidak. Karena itu, penyembahan bukan sekedar kegiatan yang dilakukan pada hari Minggu; penyembahan harus dilakukan setiap hari. ${ }^{51}$

\section{Hidup dalam Kekudusan}

Bait Allah memiliki kaitan erat dengan kekudusan. Kekudusan adalah nilai sakral yang terlekat erat pada Bait Allah. Karena Allah adalah kudus, maka ketika Ia hadir di Bait-Nya, Bait Allah itu menjadi kudus karena-Nya. Sebagaimana Bait Allah fisik kudus, demikian pula Bait Allah rohani terpaut erat dengan kekudusan tersebut.Kekudusan merupakan pokok penting yang diajarkan dalam Alkitab. Mulai dari Perjanjian Lama sampai pada Perjanjian Baru, kekudusan selalu diungkapkan secara tersirat ataupun tersurat. Kekudusan bukan saja menjadi pokok penting dimasa lalu, tetapi juga masa kini dan masa yang akan datang.

Menurut Henry Thiessen, kata kerja "menguduskan" paling tidak memiliki tiga arti: membuat atau mengakui patut dimuliakan, menganggap suci; memisahkan dari hal-hal duniawi dan

50 John MacArthur, Prioritas Utama dalam Penyembahan (Bandung: Yayasan kalam Hidup, 1983), 37.

${ }^{51}$ Judson Cornwall, Let Us Worship: Panggilan untuk Menjadi Penyembahyang Benar (Yogyakarta: Yayasan Andi, 2009), 47. 
mempersembahkan kepada Tuhan, menahbiskan; serta menyucikan. Pada umumnya, pengudusan dapat didefinisikan sebagai memisahkan diri untuk Allah, memperhitungkan Kristus sebagai kekudusan kita, dibersihkan dari kejahatan moral, serta menjadi serupa dengan gambaran Kristus. $^{52}$

Berdasarkan konsep kekudusan yang dikemukakan di atas, dapat dikatakan bahwa kekudusan bertolak dari hakikat Allah yang kudus, sehingga segala sesuatu yang berhubungan dengan-Nya harus kudus. Dikuduskan berarti dipisahkan dan dikhususkan. Lawan dari kekudusan adalah kecemaran (Yunani: akatharsia). Kekudusan berarti keterpisahan dari kecemaran. Dalam konteks penebusan, Kristus menjadi dasar dan teladan kekudusan orang-orang percaya. Kekudusan orang percaya dimulai dari Kristus sendiri.

Perjanjian Baru menyatakan bahwa orang-orang percaya adalah orang-orang kudus, umat Allah. Semua orang percaya dipandang sebagai orang yang dikuduskan di dalam Kristus. ${ }^{33}$ Dalam kaitannya dengan penggunaan istilah Bait Allah, menurut Morris menyatakan bahwa istilah ini cocok dengan gambaran orang-orang beriman sebagai "orangorang kudus" (Paulus tidak pernah berbicara mengenai seorang individu sebagai seorang kudus; ia melihat seluruh kelompok sebagai orang kudus). ${ }^{54}$

Tidak diragukan lagi bahwa setiap orang percaya terpanggil untuk hidup dalam kekudusan. Panggilan untuk hidup dalam kekudusan berlaku sepanjang masa dalam kehidupan umat Allah. Dosa-dosa yang ada dalam jemaat di Korintus pada saat itu juga masih seringkali muncul dalam komunitas Kristen masa kini. Gereja masa kini masih belum luput dari dosa perpecahan, perselisihan, masalah-masalah perkawinan dan percabulan, ketidakadilan, dan lain sebagainya. Ini berarti, hidup dalam kekudusan menjadi suatu urgensi yang berlaku bukan saja bagi umat Allah zaman dulu tetapi juga umat Allah masa kini.

Pengudusan mengandung sasaran eskatalogis. ${ }^{55}$ Dalam Surat 1 Tesalonika 3:13;5:23 (bnd. Ef. 5:27, Kol. 1:22), dikatakan bahwa kekudusan merupakan hal yang penting hingga pada saat kedatangan Yesus yang kedua kali. Ini berarti kekudusan perlu dijaga dan

\footnotetext{
${ }^{52}$ Henry C. Thiessen, Teologi Sistematika, (Malang: Gandum Mas, 1992), 441-442.

${ }^{53}$ George Eldon Ladd, Teologi Perjanjian Baru jilid 2 (Bandung: Yayasan Kalam Hidup, 1993), 302.

${ }^{54}$ Leon Morris, Teologi Perjanjian Baru, (Malang: Gandum Mas, 2006), 107-108.

${ }^{55}$ George Eldon Ladd, Teologi Perjanjian Baru Jilid 2 (Bandung: Yayasan Kalam Hidup, 1993), 302.
} 
dikembangkan dalam kehidupan orang percaya secara progresif sampai pada akhirnya, dimana orang-orang percaya berkumpul bersama Allah di dalam Surga. J. C. Ryle mengatakan bahwa "pengudusan adalah suatu gerakan dalam jiwa kita; pengudusan bertumbuh dan bertambah sepanjang hidup kita di dunia. Pembenaran memberi kita kuasa untuk masuk ke Surga, pengudusan mempersiapkan kita untuk menikmati kehidupan di surga".

Panggilan untuk hidup dalam kekudusan adalah panggilan yang berawal dari Allah di dalam Kristus. Allah memanggil orang-orang yang percaya kepada-Nya untuk hidup dalam kekudusan, bukan saja hari ini, tetapi juga esok dan seterusnya sampai Kristus datang kedua kali. Michael R. Brown mengatakan bahwa: "Allah sendiri yang memanggil kita untuk hidup kudus dan Ia menghendaki kita kudus karena Dia adalah kudus. Tanpa kekudusan tidak mungkin kita berkenan kepadaNya.tanpa kekudusan kita tidak mungkin memenuhi tujuan Allah menciptakan manusia". ${ }^{57}$ Kekudusan ialah panggilan tertinggi bagi orang Kristen dan tujuan daripada hidupnya. ${ }^{58}$

\section{Hidup dalam Pelayanan}

Salah satu aspek lain yang tercermin dari Bait Allah adalah pelayanan. Di Bait Allah terlihat jelas kegiatan pelayanan: pelayanan kepada Tuhan dan pelayanan kepada sesama. Orang-orang Lewi adalah orang-orang yang dikhususkan untuk melayani Tuhan dan melayani umat Israel. Mereka mengabdikan dirinya sepanjang hidup mereka untuk pelayanan di Bait Allah. Meski orang percaya masa kini, bukan orang Lewi, tetapi prinsipnya tetap sama; orang percaya memiliki tanggung jawab untuk melayani Tuhan dan melayani sesama.

Menurut Andar Ismail, ada empat kata yang digunakan dalam Perjanjian Baru yang berarti pelayanan. Keempat kata itu adalah diakoneo, douleo, leitourgeo dan latreuo.Diakoneo berarti menyediakan makanan di meja untuk majikan. Orang yang melakukannya disebut diakonos dan pekerjaannya disebut diakoninia. Douleo adalah menghamba yang dilakukan oleh seorang budak (doulos). Leitourgeo berarti bekerja untuk kepentingan rakyat atau kepentingan umum sebagai lawan dari bekerja untuk kepentingan diri sendiri. Orang yang melakukannya disebut

\footnotetext{
${ }^{56}$ J. C. Ryle, Aspek-Aspek Kekudusan (Surabaya: Momentum, 2010), 19.

${ }^{57}$ Michael R. Brown, Melawan Godaan Dosa: Pedoman Praktis Hidup Kudus, (Yogyakarta: Yayasan Andi, 2008), 259.

${ }^{58}$ Ensiklopedia Alkitab Masa Kini, s.v. "kudus, kekudusan"
} 
leitourgos dan pekerjaannya disebut leitourgia. Latreou berarti bekerja untuk mendapat latron yaitu gaji atau upah. Dalam PB kata ini digunakan dalam arti menyembah atau beribadah kepada Tuhan (Mat. 4:10; Kis. 7:7). ${ }^{59}$

Dari penjelasan di atas, Perjanjian Baru menunjukkan bahwa pelayanan memiliki berbagai macam bentuk dan makna. Berbagai kata digunakan untuk menyatakan pelayanan menunjukkan bahwa pelayanan itu sendiri memiliki arti yang luas dan dapat mencakup berbagai segi dan aspek kehidupan manusia. Pelayanan merupakan tindakan aktif yang dilakukan seseorang kepada orang lain (atau kepada Tuhan), bukan kepada dirinya sendiri. Pelayanan berorientasi bagi kepentingan orang lain, bukan kepentingan diri sendiri.

Selain keempat kata di atas, G. Riemer menyebutkan bahwa ada dua kata lagi yang juga dapat berarti pelayanan yaitu therapeuein dan huperetein. Therapeuein berarti orang yang bekerja sebaik-baiknya demi kesejahteraan, keselamatan orang, binatang. Huperetein berarti bekerja dengan baik menurut instruksi dari atas. ${ }^{60}$ Dalam kedua kata ini terlihat ditekankan pentingnya kualitas pelayanan yang dilakukan yaitu dengan sebaik-baiknya.

Pelayanan sangat berguna bagi pembangunan dan pertumbuhan jemaat. Bait Allah sebagai kumpulan orang percaya perlu membangun dirinya agar tidak binasa. Herman Ridderbos mengatakan bahwa pembangunan ini harus dilihat terutama sebagai kelanjutan karya Allah dengan umat-Nya, di mana gereja adalah bait dan tempat kediaman-Nya. Bagi pembangunan ini, Allah memperlengkapi gereja dengan berbagai anugerah dan kuasa, dan dengan berbagai pelayanan yang harus melanjutkan pembangunan ini. ${ }^{61}$ Paulus secara khusus memperhatikan pembangunan mutual. Hal ini pertama-tama berkenaan dengan relasi yang benar antar komunitas dan individual, keterlibatan dan fungsi individu secara keseluruhan, tetapi juga dengan bagaimana jemaat meletakkan kebaikan gereja diatas pilihan dan kemampuannya. ${ }^{62}$

Dengan demikian, dapat dijelaskan bahwa dengan saling melayani, orang-orang percaya akan dapat bertumbuh dalam segala hal ke arah Kristus yang adalah Kepala. Jika orang Kristen mengabdikan dirinya

\footnotetext{
${ }^{59}$ Andar Ismail, Selamat Melayani (Jakarta: BPK Gunung Mulia, 2003), 3-4.

${ }^{60}$ G. Riemer, Jemaat yang Diakonal (Jakarta: Yayasan Komunikasi Bina Kasih/OMF, 2004), 46.

${ }^{61}$ Herman Ridderbos, Paulus: Pemikiran Utama Teologinya, (Surabaya: Momentum, 2010), 460

${ }^{62}$ Ibid., 459.
} 
untuk melayani sesama (pertama-tama melayani saudara seiman dan kemudian orang lain yang belum percaya), maka mereka bukan saja membangun diri mereka tetapi juga mengembangkan kesatuan dan kasih yang sejati. Tugas dan tanggung jawab pelayanan berbeda-beda bagi setiap orang. Tom Jacobs menyebutnya dengan "pelayanan hirarki" dan "pelayanan Gereja". Pelayanan hirarki adalah suatu pengabdian di dalam gereja, sedangkan pelayanan gereja langsung terarah kepada dunia. ${ }^{63}$ Namun demikian, apa pun bentuk pelayanan itu, semuanya harus bermuara pada pernyataan kasih dan kemuliaan Allah semata, karena tujuan pelayanan adalah memuliakan Allah.

\section{PENUTUP}

\section{Kesimpulan}

Pertama, Bait Allah berarti kumpulan orang percaya. Sebagai kumpulan orang percaya, maka Bait Allah terdiri dari orang-orang yang percaya kepada Kristus. Orang-orang dari berbagai latar belakang kehidupan dan karakter, terkumpul menjadi satu, membentuk Bait Allah. Kedua, Bait Allah adalah tempat kediaman Allah. Dalam surat Korintus ini, kehadiran Allah ditengah-tengah umat-Nya diungkapkan dalam kehadiran Roh-Nya. Rasul Paulus menyatakan bahwa, orangorang percaya sebagai Bait Allah juga adalah tempat kediaman Allah, karena Allah berkenan hadir dan berdiam ditengah-tengah perkumpulan ini. Ketiga, Bait Allah itu harus dipelihara. Bait Allah sebagai bangunan milik Allah tidak boleh dibinasakan atau dihancurkan dengan cara apapun. Bait Allah harus dijaga kemurniannya dan keberadaannya sebagai tempat yang menyatakan kebenaran Allah. Banyak hal yang dapat mengancam eksistensi Bait Allah. Keempat, Bait Allah itu kudus. Bait Allah sebagai orang percaya dikatakan kudus karena mereka adalah milik Allah dan Allah berdiam di dalam mereka. Segala sesuatu yang memiliki hubungan langsung dengan Allah harus kudus.

Implikasi makna Bait Allah tersebut bagi orang percaya masa kini adalah: Pertama, Orang percaya masa kini patut hidup dalam kesatuan. Sebagaimana orang-orang percaya di Korintus terhisab dalam sebuah persekutuan Kristen, demikian pula dengan orang Kristen masa kini. Sebagai kumpulan orang percaya, maka orang-orang percaya harus hidup

\footnotetext{
${ }^{63}$ Tom Jacobs, Gereja menurut Vatikan II (Yogjakarta: Kanisius, 1988), 54
} 
dalam kesatuan. Kedua, hidup dalam penyembahan. Orang percaya harus hidup sebagai penyembah yang sejati dalam seluruh aspek kehidupannya. Ketiga, hidup dalam kekudusan. Sebagai Bait Allah rohani, orang percaya masa kini patut hidup dalam kekudusan yang sejati. Hidup dalam kekudusan berarti hidup memisahkan diri untuk Allah dan berusahan untuk menjadi serupa dengan Kristus. Keempat, hidup dalam pelayanan. Pelayanan adalah anugerah yang diberikan Tuhan kepada setiap orang percaya sesuai dengan karunia yang dimilikinya. Dengan saling melayani, orang-orang dapat membangun tubuh Kristus dalam kasih.

\section{KEPUSTAKAAN}

\section{Alkitab}

Alkitab Terjemahan Baru Bahasa Indonesia. Jakarta: Lembaga Alkitab Indonesia, 1974.

Alkitab Bahasa Indonesia Sehari-hari. Jakarta: Lembaga Alkitab Indonesia, 1985.

New King James Version. USA: United Bible Society, 1985.

\section{Kamus, Ensiklopedi, Konkordansi}

Ensiklopedi Alkitab Masa Kini Jilid I. Jakarta: Yayasan Komunikasi Bina Kasih/OMF, 1999.

Strong, James.Strong's Exhaustive Concordance of The Bible (Iowa: World Bible Publisher, n.d.

Buku

Barclay, William Duta Bagi Kristus - Latar Belakang Peta Perjalanan Paulus. Jakarta: BPK Gunung Mulia, 1985.

Boice, James Montgomery. Dasar-Dasar Iman Kristen. Surabaya: Momentum, 2011.

Brauch, Manfred T. Ucapan Paulus yang Sulit, Malang: Seminary Alkitab Asia Tenggara, 1999. 
Brown, Michael R. Melawan Godaan Dosa: Pedoman Praktis Hidup Kudus. Yogyakarta: Yayasan Andi, 2008.

Chamblin, J. Knox. Paulus dan Diri: Ajaran Rasuli bagi Keutuhan Pribadi. Surabaya: Momentum, 2011.

Clarke, Adam The New Testament Commentary and Critical Notes, Vol. V. Nashville: Abingdon Press, 1966.

Cornwall, Judson. Let Us Worship: Panggilan untuk Menjadi Penyembah yang Benar. Yogyakarta: Yayasan Andi, 2009.

Darmaputera, Eka. Menyembah dalam Roh dan Kebenaran: Khotbah-Khotbah tentang Kehidupan Beribadah dan Bergereja yang Kontekstual. Jakarta: BPK Gunung Mulia, 2005.

Drane, John Memahami Perjanjian baru-Pengantar Historis Teologis. Jakarta: BPK Gunung Mulia, 2009.

Ellingworth, Paul dan Howard Hatton, Surat Paulus yang Pertama kepada Jemaat di Korintus. Jakarta: Lembaga Alkitab Indonesia dan Yayasan Karunia Bakti Budaya Indonesia, 2010.

Groenen, C. Pengantar Ke Dalam Perjanjian Lama. Yogyakarta: Kanisius, 1980.

Guthrie, Donald. Teologi Perjanjian Baru, Jil. 3. Jakarta: BPK Gunung Mulia, 1993.

Ibrahim, David. Pelajaran Surat 1 Korintus. Jakarta: Mimery Press, 1999.

Ismail, Andar. Selamat Melayani. Jakarta: BPK Gunung Mulia, 2003.

Jacobs, Tom. Gereja menurut Vatikan II. Jogjakarta: Kanisius, 1988.

King, Philip J. dan Lawrence E. Stager, Kehidupan Orang Israel Alkitabiah. Jakarta: BPK Gunung Mulia, 2001.

Kristianto, Billy. Ajarlah Kami Bertumbuh: Refleksi atas Surat 1 Korintus. Surabaya: Moementum, 2011.

Ladd, George Eldon. Teologi Perjanjian Baru, Jil. 2. Bandung: Yayasan Kalam Hidup, 1999.

MacArthur, John. Prioritas Utama dalam Penyembahan. Bandung: Yayasan kalam Hidup, 1983.

Marxsen, Willi. Pengantar Perjanjian Baru: Pendekatan Kritis Terhadap Masalah-Masalahnya. Jakarta: BPK Gunung Mulia, 2012.

Morris, Leon.The First Epistle of Paul to The Corinthians. Michigan: Wm. B. Eerdmans Publishing Company, 1979.

.Tyndale New Testament Commentaries: 1 Corinthians. Michigan:

Wm. B. Eerdmans Publishing Company, 1985.

Teologi Perjanjian Baru. Malang: Gandum Mas, 2006. 
Mounce, William D. Basic Of Biblical Greek. Malang: SAAT, 2011.

Newmann, Barclay M. Kamus Yunani - Indonesia. Jakarta: BPK Gunung Mulia, 1991.

Peterson, David. Engaging with God: A Biblical Theology of Worship. Illinois: Intervarsity Press, 1992.

Pfeifer, Charles F. dan Everett F. Horisson (ed.), Tafsiran Alkitab Wycliff Vol.3 (Malang: Gandum Mas, 2001.

Pfitzner, V.C. Ulasan atas 1 Korintus-Kesatuan dalam Kepelbagaian. Jakarta: BPK Gunung Mulia, 2010.

Poole, Matthew.A Commentary on The Holy Bible, Vol. III: Matthew - Revelation (Virginia: Macdonald Publishing Company, n.d.

Reinecker, Fritz. A Lingiustik Key to The Greek New Testament. Michigan: Regency Reference Library, 1980.

Ridderbos, Herman. Paulus: Pemikiran Utama Teologinya. Surabaya: Momentum, 2010.

Riemer, G. Jemaat yang Diakonal. Jakarta: Yayasan Komunikasi Bina Kasih/OMF, 2004.

Russel P. Pertama dan Kedua Korintus. Malang: Gandum Mas, 2009.

Ryle, J. C. Aspek-Aspek Kekudusan. Surabaya: Momentum, 2010.

S. Jusuf B. Kemah Suci - Pelajaran Alkitab dalam Keluaran 25 - 40, Jilid I, n.p: 1994.

Suawa, Ferdinand K. Memahami Gramatika Dasar Bahasa Yunani Koine. Bandung: Yayasan Kalam Hidup, 2009.

Sutanto, Hasan. Perjanjian Baru Interlinear Yunani - Indonesia. Jakarta: Lembaga Alkitab Indonesia, 2003.

Thiessen, Henry C. Teologi Sistematika. Malang: Gandum Mas, 1992.

Tidball, Derek J. Teologi Penggembalaan, Malang: Gandum Mas, 1995.

Timothy and Barbara Friberg, Analitycal Greek New Testament, Michigan: Baker Book House, 1981.

Tjandra, Lukas.Latar Belakang Perjanjian Baru I. Malang: Seminari Alkitab Asia Tenggara, 1996.

Van Thuan, Francis Xavier Kardinal Nguyen. Kesaksian Pengharapan. Jakarta: Yayasan Obor, 2002.

Walvoord, John F. and Roy B. Zuck, The Bible Knowledge Commentary. Illinois: Victor Books, 1986.

Wenham, J. W. Bahasa Yunani Koine. Malang: SAAT, 1987.

Wiersbe. Warren W. Hikmat di dalam Kristus. Bandung: Kalam Hidup, 1983. 
Lembaga Alkitab Indonesia, "l Korintus" diakses tanggal 12 April 2013 tersedia di Tersedia di: http://operatif.blog.com/2011/03/30/ikorintus/

Makjen Petrus Simanjuntak, Blog Risalah Teologi“Tafsir I \& II Korintus” diakses tanggal 10 April 2013; Tersedia di:http://risalahteologi.blogspot.com/2009/01/diktat-i-dan-iikorintus.html

Sabda, "Pengantar Full Life Surat 1 Korintus" diakses tanggal 7 April 2013. Tersedia di http:// www.sabda.org/sabdaweb/biblical/intro/?b=47. www.bible-truths-revealed.com

Ebta Setiawan, Kamus Besar Bahasa Indonesia Offline, versi 1.1.

PC Study Bible.

Bible Works 7. 